\title{
THE ROAD TO RETENTION: A CLOSER LOOK AT INSTITUTIONS THAT ACHIEVE HIGH COURSE COMPLETION RATES
}

\author{
Janet C. Moore \\ The Sloan Consortium
}

Marie J. Fetzner

Monroe Community College

\begin{abstract}
Although online course completion rates are commonly believed to be lower than in other delivery modes, some programs achieve equal or better course completion rates. This issue presents studies that suggest certain practices contribute to student success. Readers are invited to contribute to work-inprogress on key factors for a framework of effective practice.
\end{abstract}

\section{KEYWORDS}

Course Completion, Retention, Student Success, Community of Inquiry, Pillars of Quality

\section{INTRODUCTION}

From 2003 to 2007, enrollment in online courses nearly doubled, from 1.98 million to 3.94 million. By 2007, the $12.9 \%$ growth rate of online enrollments far exceeded the $1.2 \%$ growth of the overall higher education student population [1]. Online education will continue to grow as a significant percentage of the 19 million enrollments in postsecondary education projected for 2010 [2]. In a climate of shifting demographics and economies, demand for higher education grows. Understanding how students succeed online can lead to far greater access and success, contributing significantly to initiatives for doubling the number of United States college graduates [3]. Yet a barrier to greater access via online education is the belief that online retention rates are lower than in other delivery modes [4].

The early growth of online education was attributed to its convenience, flexibility and affordability. But many regarded it as a novelty, a second best alternative to face-to-face education. Today, however, the success of online education is more authoritatively attributed to its quality:

For both first-year students and seniors, the percent of courses delivered primarily online was significantly related to level of academic challenge [italics added]. Online courses seem to stimulate more intellectual challenge and educational gains. This suggests that integrating technology-enhanced courses into the curriculum for all students might have some salutary benefits [5].

That cautious conclusion of the 2008 National Survey of Student Engagement (NSSE) was followed in 2009 by a stronger one from a United States Department of Education analysis of empirical research:

Students who took all or part of their class online performed better, on average, than those taking the same course through traditional face-to-face instruction. Learning outcomes for students who 
engaged in online learning exceeded those of students receiving face-to-face instruction... [6]

While these findings support the vision of online access to educational quality, scale and breadth that has spurred innovation since 1978 when Hiltz and Turoff envisioned a nation of networked education [7], online success rates are commonly claimed to be 10-20\% lower than success rates in face-to-face courses.

In an environment in which 6-year completion rates for a baccalaureate are only $56 \%$ and achievement gaps are widening at all educational levels, retention is an increasingly recognized indicator of institutional effectiveness. For example, the Higher Education Act Reauthorization gives consumers decision-making information via College Navigator, a web site that provides 27 categories of information about each institution that participates in Title IV programs:

...institutional mission; statistics on applications, admission, enrollment, SAT or ACT scores, transfer students, male and female students, in-state and out-of-state students, racial and ethnic groups, disabled students, degrees awarded, time to completion of degrees, faculty, cost of attendance and financial aid; alternative tuition plans; and campus safety information. ...[and] in a sortable and searchable format, information on the cost of higher education for each institution that participates in Title IV programs [8, 9].

Just as the quality of an individual course is a confluence of teacher and learner expertise, academic challenge and design, technology and resources, and support services, each of the College Navigator categories reflects on the quality of an institution and the leaders who advance its mission. Each category influences institutional and individual success. As digital culture advances, public performance ratings will increasingly influence consumer choice. Calls for accountability lead to the rise of public ratings that are published by individuals and both non-profit [10] and commercial groups [11]. Ratings are not uniformly reliable [12] and choosing the right online program is still a daunting task; but as quality indicators become more public, sharing the frameworks and practices that support effective online education is in the interests of every institution.

Thus, this special issue asks:

Why do some institutions achieve strong online course completion rates?

What common practices do these institutions share?

Can common practices begin a framework to guide retention efforts in diverse online contexts?

Reasoning from results to determine cause, the case studies in Part I address these questions. Six institutions that were featured in Volume 10:3 of the Journal of Asynchronous Learning Networks (JALN) [13] present practices that contribute to course completion rates of $85 \%$ or more. Common practices are compiled in a preliminary framework.

The collaborative and empirical study, "An Exploration of the Relationship Between Indicators of the Community of Inquiry Framework and Retention in Online Programs," finds that students experiencing effective social interactions are most likely to persist from one semester to the next.

Part II collects previously published empirical JALN studies on retention. We republish them here because their literature reviews, sample surveys and insights about the experience of online learners are useful in diverse institutional contexts. 
Readers are welcome to comment and to contribute to developing a framework for retention practices at the Sloan Consortium website: http://www.sloanconsortium.org/node/2486.

\section{CASE STUDIES}

Six case studies are included in Part I of this issue. All six institutions share a definition of online course asynchronicity; namely, at least $80 \%$ of the course is online, requiring at most $20 \%$ face-to-face presence. This threshold follows the Sloan-C definition that courses delivered asynchronously $80 \%$ or more of the time are considered online courses as distinguished from blended, hybrid, mixed-mode or web-enhanced courses that require more face-to-face participation. The case studies are from institutions that have sustained high growth rates and high online course success rates for at least five years [9].

Focusing first on 100- and 200-level courses, four institutions report on how they have achieved student success rates of $85 \%$ or more in courses in which rates are customarily lowest in any delivery mode [14]. We focus on 1- and 200 level courses because beginning students are more likely to opt out than advanced students. In addition, two institutions report on very high graduate program or overall course success rates. Table 1 shows the range of institutions by overall size, acceptance rates, and the proportion of online enrollments in Fall 2008; it includes links to institutional websites and online program portals. Appendix A provides institutional mission statements.

\begin{tabular}{|c|c|c|c|}
\hline & Type of Institution & $\begin{array}{l}\text { Acceptance } \\
\text { Rate }\end{array}$ & $\begin{array}{c}\text { Online } \\
\text { Enrollments in } \\
\text { Fall } 2008 \\
\text { (estimated \% } \\
\text { of total } \\
\text { Enrollment) }\end{array}$ \\
\hline \multicolumn{4}{|c|}{ Undergraduate 1-and 200 level course success rates above $85 \%$} \\
\hline $\begin{array}{l}\text { Peirce College } \\
\text { http://peirce.edu/ } \\
\text { http://peirce.edu/Online.aspx } \\
\text { Philadelphia, PA }\end{array}$ & $\begin{array}{l}\text { Small, } \\
\text { 4-year, Private not-for- } \\
\text { profit }\end{array}$ & $\begin{array}{l}\text { Open } \\
\text { admissions }\end{array}$ & $\begin{array}{l}3516 \\
(64 \%)\end{array}$ \\
\hline $\begin{array}{l}\text { University of Illinois, Springfield } \\
\text { http://www.uis.edu/ } \\
\text { http://www.uis.edu/online/ } \\
\text { Springfield, IL }\end{array}$ & $\begin{array}{l}\text { Small, } \\
\text { 4-year, Public }\end{array}$ & $60 \%$ & $\begin{array}{l}3815 \\
(25 \%)\end{array}$ \\
\hline $\begin{array}{l}\text { Rochester Institute of Technology } \\
\text { http://www.rit.edu/ } \\
\text { http://online.rit.edu/ } \\
\text { Rochester, NY }\end{array}$ & $\begin{array}{l}\text { Medium, } \\
\text { 4-year, Private not-for- } \\
\text { profit }\end{array}$ & $60 \%$ & $\begin{array}{l}9,121 \\
(5 \%)\end{array}$ \\
\hline $\begin{array}{l}\text { University of Cincinnati } \\
\text { http://www.uc.edu/ } \\
\text { http://www.uc.edu/distance/ } \\
\text { Cincinnati, Ohio }\end{array}$ & $\begin{array}{l}\text { Large, } \\
\text { 4-year, Public }\end{array}$ & $75 \%$ & $\begin{array}{l}2800 \\
(8 \%)\end{array}$ \\
\hline \multicolumn{4}{|c|}{ Graduate and overall success rates above $90 \%$} \\
\hline $\begin{array}{l}\text { SetonWorldwide of Seton Hall University } \\
\text { http://www.shu.edu/ } \\
\text { http://www.shu.edu/academics/setonworldwide } \\
\text { South Orange, NJ }\end{array}$ & $\begin{array}{l}\text { Medium, } \\
\text { 4-year, Private not-for- } \\
\text { profit }\end{array}$ & $73 \%$ & $\begin{array}{l}\text { Graduate } \\
3132 \\
(9 \%)\end{array}$ \\
\hline
\end{tabular}




\begin{tabular}{|l|l|l|l|}
\hline $\begin{array}{l}\text { Dallas Baptist University } \\
\text { http://www.dbu.edu/ }\end{array}$ & $\begin{array}{l}\text { Small, } \\
\text { 4-year, Private not-for- } \\
\text { http://dbu.edu/online }\end{array}$ & $47 \%$ & $\begin{array}{l}\text { Overall } \\
5200 \text { online } \\
\text { enrollments } \\
(32 \%)\end{array}$ \\
\hline Dallas, TX & profit & \\
\hline
\end{tabular}

Table 1. Institutions with High Online Success Rates in Beginning Courses, Graduate Courses and/or Overall Enrollments: Small <5,000; Medium< 15,000; Large> 15,000

Standards and definitions for success online are no less daunting than they are in traditional delivery modes. To begin to develop a framework which might be useful across institutions, the case studies in this issue use the Sloan-C pillars of quality to explore commonalities and differences in their distinctive contexts. The goal of Sloan-C's quality framework (see Appendix B) is that any learner who engages in online education should have, at a minimum, an education that represents the quality of the provider's overall institutional quality and better, learning outcomes that meet professional and industry standards. Any institution can use the pillars as metrics by demonstrating progress towards quality goals in five inter-related areas: learning effectiveness, access, scale (capacity enrollment achieved through costeffectiveness and institutional commitment), faculty satisfaction, and student satisfaction [15]. The pillar framework is intentionally flexible to be useful in any context-it works at the mission, department, program and course levels. As one of the case study authors points out, the starting point is, "the imperative to look within" [5]; thus, the institutional mission is the source for specific goals in each of the pillars.

In these institutions high success rates in online courses appear to be a product of institutional cultures that are committed to student success. Key people enact institutional policies in academic, technology and support offices using metrics to guide practices that achieve the goal of accessible education. One question that emerges from this review of effective practices is, "Do institutions with high online success rates focus the majority of their efforts on a particular pillar or set of pillars?” With this question in mind, in brief, representative practices drawn from the case studies as a whole are outlined below. Appendix C is a composite list of practices in place at each institution categorized by the Sloan-C five pillars of quality [16].

\section{A. Access}

The goal for access is that all learners who wish to learn online have the opportunity and can achieve success. Providing additional access to higher education is as appealing to institutions as anytime, anywhere learning is to prospective students. But one size does not fit all. For example, in many institutions and particularly in institutions that serve students with lower SAT scores and higher Pell grant levels, expenditures on student services that improve access are demonstrably related to retention and graduation rates [17]. Despite the efforts of rating agencies, it remains difficult to find the online program that aligns with individual learner needs and preferences. Thus, the challenge access brings is accommodating learners so that the course or program matches the institution's strengths with students' skills and interests, in ways that nurture a strong sense of belonging to an "inclusive educational and social community” [18].

\section{Personalize}

Thus, these successful institutions aim to personalize relationships via marketers, advisors, troubleshooters, peers and coaches throughout the student's academic career, even dedicating individual administrative or programmatic advisors who use established protocols in working with individual learners. Institutions introduce learners to the community in several ways: through a first year experience, through online student community websites, through face-to-face and online student orientations, and 
The Road to Retention: A Closer Look at Institutions that Achieve High Course Completion Rates

through introductory courses to encourage online students to share concerns, questions, and solutions. One institution groups its online students into cohorts to promote community teamwork and sustained involvement, beginning with a week-end on-campus residency before classes begin [19].

\section{Prepare and Assist}

To prepare students for the significantly more active role that online learners must adapt to, institutions provide on-campus and/or online orientations to procedures, role adjustment and expectations. Setting the stage for student expectations is key, and these preparatory efforts assist in that effort. So that learners (faculty too) can get technical help whenever they need it, 24/7 online help desks are a boon for all, residential as well as online. Going beyond technical help, institutions also provide academic support, tutoring, library, registrar, financial and other support services online, including skill assessments before taking an online class. One institution provides free software so students have what they need to complete courses, and another institution provides free interlibrary loan services to online students.

\section{Design and Observe}

Once students are enrolled in courses, online delivery offers advantages in terms of designing for students with different learning styles and abilities. Understanding that students respond to interactivity differently (e.g. deaf and hard of hearing students' responses suggest they are even more favorable to higher levels of interaction than hearing students), one institution transcribes and captions media for the online learning environment; this service has proven to benefit all students who use the transcriptions for review. Another key for retaining students is using Learning Management Systems (LMSs) to observe how students are using features and interacting with the course. These observations are useful for refining design and for helping to identify and intervene with students at risk for non-completion.

\section{B. Faculty Satisfaction}

The goal for faculty satisfaction is the sense that teaching online is personally and professionally beneficial, an enthusiasm that communicates itself to students. Thus, institutional leadership endorses online faculty excellence, recognizing the benefits and the demands of online teaching and providing ongoing professional development, support, and recognition.

\section{Introduce Online Teaching}

At these institutions, faculty members and their respective programs are actively involved in content development and curriculum design, internal and external quality reviews, and community building. Initially, faculty are introduced to online teaching via online and/or face-to-face workshops, ensuring faculty have experience as online learners and benefit from received knowledge before they begin teaching online. Technology and instruction services occur online and at convenient places such as in campus libraries. For new instructors, institutions provide boilerplates and placeholders including a series of effective practices as for course design and delivery, often using institutional and/or external standards or rubrics. Faculty may also view sample online courses that illustrate effective practices in online teaching. They are supported via helpdesks, instructional designers, and technology and academic resource centers (e.g. http://ftrcucedu and http://wwwucedu/cetl/), and they know that additional professional development is available. The institutions survey and interview faculty to understand and improve faculty satisfaction with online teaching.

\section{Provide Ongoing Professional Development and Support}

To support the design and development of effective online courses and programs, institutions dedicate support from instructional designers, disability services, advisors, librarians and other personnel, 
including a team member assigned to make sure all course links are working, dates are set correctly, and exams and quizzes are functioning. Additional support includes peer consulting and mentoring. Institutions provide or subscribe to an array of ongoing professional development workshops for new and experienced faculty with topics such as:

- understanding differences between online and face-to-face teaching

- reconceptualizing courses for online delivery co-teaching and team teaching

- prioritizing pedagogical priorities

- understanding copyright and intellectual property

- managing workload

- $\quad$ using Web 2.0 applications

- designing and managing effective discussions and

- creating and engaging students in online learning community

New and experienced online faculty benefit from teaching centers that emphasize prioritizing pedagogy, using teaching practices that have been demonstrated as effective, and being current with the scholarship of teaching and learning (e.g. the Center for Enhancement of Teaching and Learning http://wwwucedu/cetl/). Communities of practice encourage faculty to share and advance effective practice and provide opportunities for cross-discipline discussions on online pedagogy and course design.

\section{Recognize Excellence}

Award and recognition programs for outstanding online teaching and courses signal institutional commitment to online education, providing exemplars that communicate effective practice in-house and beyond the institution. One institution denotes award winning online courses in its course listings. Endorsing excellence, institutions link online teaching and quality reviews to promotion and tenure or other benefits such as funding for conference attendance, research presentations, and mentoring activities. Some institutions create various royalty arrangements or release time for teaching or developing online courses. Others provide additional compensation for research about online education and for developing courses and effective practices.

\section{Learning Effectiveness}

\section{Compare Outcomes in Delivery Modes}

The goal for learning effectiveness online is that learning outcomes meet or exceed industry and professional standards. As reported by NSSE and the Department of Education [5, 6], these goals are achievable. As we continue to learn about improving outcomes, institutions compare the differences in outcomes in delivery modes and use the comparisons to identify the components of effective pedagogy that can be used in all modes. Institutions regularly review and critique online courses to improve them; they recommend using the same curricula to achieve the same learning outcomes in face-to-face instruction and online delivery, understanding the affordances that support learning activities in the various modalities.

\section{Emphasize Interaction}

An especially important finding results in an emphasis on intensive faculty-student and student-student interactivity [20] that foregrounds teaching, cognitive and social presence. At least one institution provides faculty with expectations for teaching presence and feedback time, and another ranks all courses' interactivity as a measure of learner engagement. 


\section{Set Policy, Assess and Benchmark Quality}

The institutions regularly use assessment tools, including course evaluations and student satisfaction surveys, regularly, to evaluate learning effectiveness and improve instructional design. Policies for class size differ among institutions according to course design, discipline and difficulty level, but the goal is to assure that class size is manageable for effective teaching and learning. Since interaction among peers engages students, the institutions advocate using LMS "groups" features for small group online discussion and team projects. They also enable feedback on effectiveness via online group project peer evaluation surveys to gather better data about what works in designing and conducting group activities.

Institutions also encourage peer tutoring because it encourages students to turn to each other so those who are reluctant to approach the teacher don't feel lost; peer tutoring or peer review also tends to give students greater confidence in negotiating their own learning. Partly for this reason, one institution uses cohort teams to help students perform and sustain learning communities due to comfort with interaction bred by familiarity with cohort members; cohort members who have to stop-out may return and join a new cohort. Another school provides on-demand tutoring that is free for students; this individual tutoring encourages students to get help as needed and stick with the program rather than giving up.

As further commitment to learning effectiveness, these institutions benchmark courses and programs inhouse and externally with other quality courses and programs.

\section{Student Satisfaction}

The goal of student satisfaction with regard to progress towards course and degree completion is that students are pleased with learning and with support experiences and feel their effort is worthwhile. Many of the components of student satisfaction have to do with effective access, personalized support, community, relationships, and relevant learning. A primary principle for student satisfaction is adopting students' perspectives and assisting them with adjusting to becoming online learners, a significant adjustment from what is generally a more passive learning role. Students may come to online education with the usual expectation of receiving relevant knowledge from a knowledgeable instructor who provides fair and reliable feedback and grades. But they may also expect convenience to equate with easiness and passivity. Instead,

while maintaining the usual expectations and privileges attached to the role of learner, online learners add such things as:

- knowledge about, skill with, and acceptance of the technology

- new modes and amounts of communication with instructors, peers and administrators

- increased levels of learner self-direction, and

- a new 'place' for learning in time (anytime, usually determined by the learner and their life circumstances) and space (anywhere, dependent upon equipment requirements) [21].

Thus, these institutions emphasize knowing their students, actively seeking their feedback, and using it for continuous improvement.

\section{Introduce Online Learning}

A one-stop shop helps introduce prospective students to what they can expect in online education, sometimes including a self-assessment "Is online learning for me?” Once students are admitted, they can use the one-stop site or student community site to get all the information they need, including advising, scheduling, registration and support. Most institutions require an orientation essentials course that includes technical and academic information about using the LMS, making effective discussion posts, accessing student services, time management, goal setting, and participating in community activities ( i.e. 
information much like that addressed in on-campus first year initiatives aimed at engaging students in the campus community). One institution requires a two-week on-campus residency to familiarize students with the institutional culture and the people with whom they will be working.

\section{Assist Completion}

The institutions are very aware of the fact that students choose online education because its asynchronicity and flexibility fit with their work and family schedules. Thus, institutions work hard to make sure courses are available when online students can take them, holding online seats for matriculated students until just before the course starts, and giving them course enrollment preferences. Institutional and peer support in student communities help students motivate each other to complete.

\section{Listen}

Students value knowing that they are an integral part of an institution that listens to them and recognizes they need to control the pace of their own multiple commitments. Thus, institutions regularly solicit and use student input, conduct online student satisfaction surveys and using results for continuous improvement, and by asking students to identify obstacles so the institution can eliminate them. Students value leadership opportunities in the online classroom, in groups or in leading discussions that better prepare them for and or align with formal electronic communications and expectations in the workforce.

\section{E. Scale}

The goal for scale is to achieve capacity enrollment, a measure of "the academy's greater appreciation of itself as a community focused on common goals" [22]. While there are a variety of business models for achieving scale [23], each of the case studies shows institutions that have grown significantly and have built infrastructures to accommodate much more learning by building reliable technical and people networks.

\section{Make Retention a Visible, Mission-driven, Institution-wide Priority}

"The whole point...is to increase access to education to a pool of learners who currently do not have this access, and so we need to be able to assess whether increased access is, in fact, being provided," [24] thus these institutions have strong leadership with an imperative for retaining students that is at least as important as recruiting them. Online programs are initiated strategically with an expectation that programs will be self-sustaining and viable, with budgets set for the number of students to be admitted annually; with estimated persistence and completion rates; and with anticipated income generated from anticipated tuition and fees aligned with investment expenditures in operational, production and infrastructure costs.

\section{Build Sustainable Models}

Each of the institutions has developed financially sustainable, scalable models with strategies for (1) developing programs , faculty, and courses; and (2)for providing student access, orientation and community [25]. They may have the same faculty teach both online and on-campus. have the majority of faculty from full-time on-campus faculty, or, in some cases, combine full-time faculty and part-time, compensating both on an adjunct overload basis. 


\section{Partner}

Case study institutions are active members of Sloan-C and of regional and national professional organizations. This participation enables them to benchmark, share research and effective practices and other resources for improving the quality of online education as new knowledge unfolds.

\section{ADDITIONAL STUDIES REPRINTED IN THIS VOLUME}

"Getting Better: ALN and Student Success" summarizes factors that influence high course success rates at 13 institutions and systems. Thanks are due to people from institutions cited in that paper for generously contributing more detailed case studies for this volume.

Two studies of retention in graduate programs approached retention from students' perspectives explaining why they left and why they stayed. Both studies include surveys that are useful for gauging student perceptions. In "Factors that Influence Students' Decision to Dropout of Online Courses" researchers wanted to know if there were reasons specific to online delivery (such as feelings of isolation and disconnectedness, or problems with technology). Student surveys showed that the reasons students gave "were not very different from those typically given by dropouts from traditional face-to-face programs [26]." In "Why They Stayed: Near-Perfect Retention in an Online Certification Program in Library Media," the review of research on online retention also finds no conclusive evidence that reasons for dropping out differ by delivery mode. Asking why students stayed in the program, researchers created a survey drawn from the models of Tinto [27], of Bean and Metzner [28], and of the Community of Inquiry Model [29]. They find that "perhaps a necessary condition of retention for this population is the program being online, and afterwards, other conditions such as academic integration and relevance to the students' work lives may be sufficient to keep them enrolled” [30]. The survey results usefully compare the reasons that motivated students to enroll and the reasons that motivated them to complete.

"Using Asynchronous Learning in Redesign: Reaching and Retaining the At-Risk Student” documents increases in retention at the course level in large introductory courses at several institutions. These are the principles of redesign:

Whole course redesign (not just a section)

Active learning (rather than lecture or other passive assignments)

Computer-based learning resources (for self-checks, audits, and demonstrations)

Mastery learning (for greater learner self-direction)

On-demand help (expanded support from many different people and groups)

Alternative staffing (to free faculty from routine tasks)

Examples of redesign amply substantiate that these practices improve online retention, learning, and scale [31].

\section{CONCLUSION AND RECOMMENDATIONS}

The last two decades witnessed rapid growth and innovation in higher education online. As the contributors to this issue know well, higher success rates are a result of institution-wide focus on improvements in access, learning effectiveness, scale and faculty and student satisfaction. The studies in this issue demonstrate that course completion rates can be as good as, and better than, course completion rates in face-to-face education. 
The papers in this issue give a gestalt of practices that positively affect student success. No doubt the elements of each practice take different shapes at each institution that adopts them. Institutions that are committed to improving student learning will need to determine the cost of implementing and maintaining practices as they determine the impact of each.

The emergence of effective practices for engaging students and motivating them to persist can best be addressed through collaboration within and across learning organizations. Appendix D is such a collaboration, a work-in-progress blog with tips for faculty for achieving greater course engagement and success. The Sloan-C Faculty Development Advisory Board invites you to join its collaboration on tips for faculty at http://www.sloanconsortium.org/node/2486, and you are welcome to comment on the studies in this issue.

\section{APPENDIX A: INSTITUTIONAL MISSIONS}

Dallas Baptist University

http://www.dbu.edu/

http://dbu.edu/online

The purpose of Dallas Baptist University is to provide Christ-centered quality higher education in the arts, sciences, and professional studies at both the undergraduate and graduate levels to traditional age and adult students in order to produce servant leaders who have the ability to integrate faith and learning through their respective callings.

\section{Seton Hall}

http://www.shu.edu/

http://www.shu.edu/academics/setonworldwide

Seton Hall is a major Catholic university. In a diverse and a collaborative environment it focuses on academic excellence and ethical development. Seton Hall students are prepared to be leaders in their professional and community lives in a global society and are challenged by outstanding faculty, an evolving technologically advanced setting and values-centered curricula.

\section{University of Illinois at Springfield}

http://www.uis.edu/

http://www.uis.edu/online/

The University of Illinois at Springfield provides an intellectually rich, collaborative, and intimate learning environment for students, faculty, and staff, while serving local, regional, state, national, and international communities. UIS serves its students by building a faculty whose members have a passion for teaching and by creating an environment that nurtures learning. Our faculty members engage students in small classes and experiential learning settings. At UIS, the undergraduate and graduate curricula and the professional programs emphasize liberal arts, interdisciplinary approaches, lifelong learning, and engaged citizenship. UIS provides its students with the knowledge, skills, and experience that lead to productive careers in the private and public sectors. UIS serves the pursuit of knowledge by encouraging and valuing excellence in scholarship. Scholarship at UIS is broadly defined. Faculty members are engaged in the scholarship of discovery, integration, application, and teaching. Excellence in teaching and meaningful service depend on a foundation of excellence in scholarship. One vital area in which UIS extends its scholarship, teaching, learning, and expertise beyond the campus is in the broad area of public affairs. From its location in the state capital, UIS shapes and informs public policy, trains tomorrow's leaders, and enriches its learning environment through a wide range of public affairs activities, programs, 
The Road to Retention: A Closer Look at Institutions that Achieve High Course Completion Rates

and organizations. UIS empowers its students, faculty, and staff by being a leader in online education and classroom technology. UIS uses technology to enhance its distinctive learning environment and extend that environment beyond the boundaries of the campus.

\section{University of Cincinnati}

http://www.uc.edu/

http://www.uc.edu/distance/

The University of Cincinnati serves the people of Ohio, the nation, and the world as a premier, public, urban research university dedicated to undergraduate, graduate, and professional education, experiencebased learning, and research. We are committed to excellence and diversity in our students, faculty, staff, and all of our activities. We provide an inclusive environment where innovation and freedom of intellectual inquiry flourish. Through scholarship, service, partnerships, and leadership, we create opportunity, develop educated and engaged citizens, enhance the economy and enrich our University, city, stateand global community.

\section{Rochester Institute of Technology}

http://rit.edu

http://online.rit.edu/

\section{Vision, Mission and Values}

Vision:

RIT will lead higher education in preparing students for successful careers in a global society.

\section{Mission:}

The RIT community engages and motivates students through stimulating and collaborative experiences. Our mission is to provide technology-based educational programs for personal and professional development. We rigorously pursue new and emerging career areas. We develop and deliver curricula and advance scholarship relevant to emerging technologies and social conditions. Our community is committed to diversity and student centeredness and is distinguished by our innovative and collaborative spirit.Internal and external partnerships expand our students' experiential learning. RIT is committed to mutually enriching relationships with alumni, government, business and the world community. Teaching, learning, scholarship, leadership development, and student success are our central enterprises.

Values:

Student Centeredness: Exhibits behavior, performs duties of position, and/or makes decisions that demonstrate and/or support the importance of students as the primary constituency of the university and/or contributes directly to student success.

Professional Development and Scholarship: Takes actions to continuously advance and/or improve in one's academic or professional discipline; as an individual contributor; as a team member; and/or as an organizational leader.

Integrity and Ethics: Does what it takes to deliver on commitments made to the department, college, or division and to constituency groups. Builds personal trust and relationships inside and outside the university by doing what one says he or she will do when it is promised.

Respect, Diversity and Pluralism: Provides a high level of service to fellow members of the RIT community. Treats every person with dignity. Demonstrates inclusion by incorporating diverse perspectives to plan, conduct, and/or evaluate the work of the organization, department, college, or division.

Innovation and Flexibility: Provides and/or encourages new ideas that could make the department, college, or division an even better organization. Open to, and adapts well to change.

Teamwork and Collaboration: Contributes to the efforts of the department, division, or college as a 
team player. Works well with others outside the department to accomplish cross-college or division goals and objectives.

\section{Peirce College}

http://peirce.edu/

http://peirce.edu/Online.aspx

Founded in 1865, Peirce is a private, four-year, specialized institution providing practical, leading edge curricula to primarily working adult learners.

\section{APPENDIX B: BRIEF VERSION OF THE QUALITY FRAMEWORK}

\begin{tabular}{|c|c|c|c|}
\hline \multicolumn{4}{|c|}{ Brief Version of the Quality Framework } \\
\hline Goal & Process/Practice & Metric (for example) & Progress Indices \\
\hline \multicolumn{4}{|c|}{ Learning Effectiveness } \\
\hline $\begin{array}{l}\text { The quality of learning } \\
\text { online is demonstrated } \\
\text { to be at least as good } \\
\text { as the institutional } \\
\text { norm and meet or } \\
\text { exceed industry and } \\
\text { professional standards. }\end{array}$ & $\begin{array}{l}\text { Academic integrity and } \\
\text { control reside with faculty } \\
\text { in the same way as in } \\
\text { traditional programs at the } \\
\text { provider institution. }\end{array}$ & $\begin{array}{l}\text { Faculty perception surveys or } \\
\text { sampled interviews compare } \\
\text { learning effectiveness in } \\
\text { delivery modes. } \\
\text { Learner/graduate/employer } \\
\text { focus groups or interviews } \\
\text { measure learning gains. }\end{array}$ & $\begin{array}{l}\text { Faculty report online } \\
\text { learning is equivalent or } \\
\text { better. } \\
\text { Direct assessment of } \\
\text { student learning is } \\
\text { equivalent or better. }\end{array}$ \\
\hline \multicolumn{4}{|c|}{ Scale } \\
\hline $\begin{array}{l}\text { The institution } \\
\text { achieves capacity } \\
\text { enrollment by } \\
\text { continuously } \\
\text { improving services } \\
\text { while reducing costs. }\end{array}$ & $\begin{array}{l}\text { The institution } \\
\text { demonstrates leadership, } \\
\text { financial, and technical } \\
\text { commitment to its online } \\
\text { programs. } \\
\text { Tuition rates provide a fair } \\
\text { return to the institution } \\
\text { and best value to learners. }\end{array}$ & $\begin{array}{l}\text { Institutional stakeholders show } \\
\text { support for participation in } \\
\text { online education. } \\
\text { Effective practices are } \\
\text { identified and shared. }\end{array}$ & $\begin{array}{l}\text { The institution sustains } \\
\text { the program, expands and } \\
\text { scales upward as desired, } \\
\text { strengthens and } \\
\text { disseminates its mission } \\
\text { and core values through } \\
\text { online education. }\end{array}$ \\
\hline \multicolumn{4}{|c|}{ Access } \\
\hline $\begin{array}{l}\text { All learners who wish } \\
\text { to learn online can } \\
\text { access learning in a } \\
\text { wide array of } \\
\text { programs and courses. }\end{array}$ & $\begin{array}{l}\text { Program entry and support } \\
\text { processes inform learners } \\
\text { of opportunities, and } \\
\text { ensure that qualified, } \\
\text { motivated learners have } \\
\text { reliable access to } \\
\text { instruction and services. }\end{array}$ & $\begin{array}{l}\text { Administrative and technical } \\
\text { infrastructure provides access } \\
\text { to all prospective and enrolled } \\
\text { learners. } \\
\text { Quality metrics for information } \\
\text { dissemination; learning } \\
\text { resources delivery; tutoring } \\
\text { services }\end{array}$ & $\begin{array}{l}\text { Qualitative indicators } \\
\text { show continuous } \\
\text { improvement in growth } \\
\text { and effectiveness rates. }\end{array}$ \\
\hline \multicolumn{4}{|c|}{ Faculty Satisfaction } \\
\hline $\begin{array}{l}\text { Faculty are pleased } \\
\text { with teaching online, } \\
\text { citing appreciation and } \\
\text { happiness. }\end{array}$ & $\begin{array}{l}\text { Processes ensure faculty } \\
\text { participation and support } \\
\text { in online education (e.g. } \\
\text { governance, intellectual } \\
\text { property, royalty sharing, } \\
\text { training, preparation, } \\
\text { rewards, incentives and so }\end{array}$ & $\begin{array}{l}\text { Repeat teaching of online } \\
\text { courses by individual faculty } \\
\text { indicates approval. } \\
\text { Addition of new faculty shows } \\
\text { growing endorsement. }\end{array}$ & 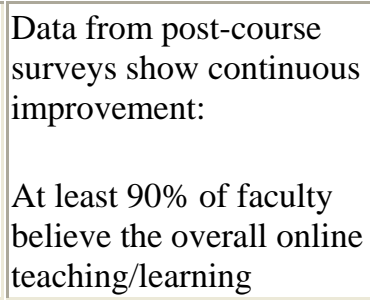 \\
\hline
\end{tabular}




\begin{tabular}{|c|c|c|c|}
\hline & on). & & $\begin{array}{l}\text { experience is positive. } \\
\text { Willingness/desire to } \\
\text { teach additional courses in } \\
\text { the program: } 80 \% \\
\text { positive. }\end{array}$ \\
\hline \multicolumn{4}{|c|}{ Student Satisfaction } \\
\hline $\begin{array}{l}\text { Students are pleased } \\
\text { with their experiences } \\
\text { in learning online, } \\
\text { including interaction } \\
\text { with instructors and } \\
\text { peers, learning } \\
\text { outcomes that match } \\
\text { expectations, services, } \\
\text { and orientation. }\end{array}$ & $\begin{array}{l}\text { Faculty/learner interaction } \\
\text { is timely and substantive. } \\
\text { Adequate and fair systems } \\
\text { assess course learning } \\
\text { objectives; results are used } \\
\text { for improving learning }\end{array}$ & $\begin{array}{l}\text { Metrics show growing } \\
\text { satisfaction: } \\
\text { Learner surveys and/or } \\
\text { interviews } \\
\text { Alumni surveys, referrals, } \\
\text { testimonials } \\
\text { Outcomes measures } \\
\text { Focus groups } \\
\text { Faculty/Mentor/Advisor } \\
\text { perceptions }\end{array}$ & 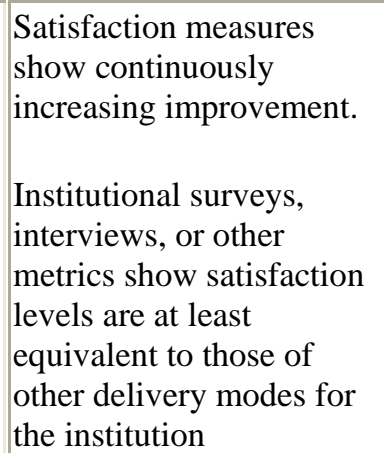 \\
\hline
\end{tabular}

\section{APPENDIX C: PRACTICES THAT CONTRIBUTE TO HIGH COURSE COMPLETION RATES}

\section{Access}

Emphasize the flexibility as well as the responsibilities of asynchronous "any-time, any-place" learning

Publicize additional access to degree completion via online courses

Personalize access via administrative or programmatic contact people, marketers, advisors, troubleshooters, and coaches throughout the student's academic career

Establish protocols for student advising

Provide students with online student skill assessments before taking an online class and offer online and/or on-campus orientations to online learning

Develop or share an online student community website or introductory course that encourages online students to share concerns, questions, and solutions

Provide academic support, tutoring and support services online, including an institutional 24/7 Help Desk to reach all students

Provide necessary software free or at a reduced rate

Leverage technology to help identify and work with students who are at-risk

\section{Faculty Satisfaction}

Share information about the benefits and demands of online teaching

Involve faculty members and their respective programs in content, curriculum design, peer quality reviews, and community building

Support faculty via a Technology Resources Center, offering technology and instruction services online and at convenient places such as in University Libraries

Require an online teaching course for new online faculty and make ongoing online professional development available for new and experienced online faculty so that faculty develop confidence and 
competence

Create boilerplates and placeholders to guide new instructors through a series of effective practices as they prepare their courses; use standards or rubrics to guide course design; develop sample online courses that illustrate effective design and practices

Provide a technical HelpDesk for faculty

Support online faculty via teaching/learning resources, peer consulting and ongoing workshops for topics such as understanding differences between online and face-to-face teaching, co-teaching and team teaching, prioritizing pedagogical priorities, copyright, tips and tricks for managing workload, designing and managing effective discussions, and for successfully creating an online learning community and engaging students

Dedicate personnel support for online faculty from instructional designers, disability services, librarians, technologists and other personnel, including team members assigned to make sure all links are working, dates are set correctly, and exams and quizzes are functioning

Conduct online surveys and interviews to measure and improve faculty satisfaction

Establish or encourage participation in venues for faculty communities of practice

Create various royalty arrangements for online courses

Provide additional compensation (seed money, operational funds, release time, etc.) to faculty for course development, research and mentoring and fund online faculty for conference attendance, research presentations, and mentoring.

Formally recognize outstanding online teaching and best courses for annual awards or recognition program

\section{Learning Effectiveness}

Compare differences online and face-to-face to validate learning effectiveness and to leverage respective affordance

Emphasize intensive faculty-student and student-student interactivity

Rank all courses' interactivity as a measure of engagement

Assure class size is manageable

Use "groups" feature for small group online discussion and team projects, measuring CMS features used as an index of interaction

Use cohort learning teams

Provide online group project peer evaluation surveys

Regularly review and critique the online courses to improve them

Benchmark courses and programs with other quality courses and programs

Use the same curricula to achieve comparable learning outcomes in face-to-face instruction and online delivery

Require or encourage prompt feedback from online faculty, explaining teaching presence expectations in advance of the course

Implement a teaching and learning technology center to help faculty and students with just-in-time academic support

Provide online peer tutors or commercial tutoring

Use assessment tools, including course evaluations and student satisfaction surveys, to evaluate learning effectiveness and improve instructional design and delivery

Understand that students respond to interactivity differently, and provide multiple options for interaction 
Transcribe and caption media for the online learning environment

\section{Scale}

Integrate online education with the institutional mission

Make retention efforts and their results visible to the institution and beyond

Evaluate production costs and seek cost effective affordances

Develop infrastructure for growth in online and blended delivery

Set a reasonable expectation of return on investment of online initiatives

Set benchmarks for the number of students to be admitted annually; estimate persistence and completion rates

Require a long-term budget plan that addresses continuing viability in proposals for online programs

Partner with professional organizations to share faculty, student, administrative resources; professional networks, professional development; funding opportunities

Build a sustainable model based on the needs of your institution. Develop a budget model that:

- Compensates faculty on an adjunct overload basis, or

- Includes a majority of online instructors from on-campus full-time faculty, or

- Includes all full-time faculty, who teach both online and on-campus

\section{Student Satisfaction}

Conduct online student satisfaction surveys and use results for continuous improvement

Identify online learning obstacles to eliminate them for students

Promote flexibility in student scheduling

Assure matriculated online students receive course enrollment preferences

Hold online "seats" for matriculated online students until just before the start of the course

Require on-campus residency or peer support for cohort learning team students

Provide low-cost or free supplemental academic support to online students

Make available a technical helpdesk for students

Respond to the need for students being able to control the pace of their lives

Support students and enable them to support each other with online student community courses or websites, including student associations

\section{APPENDIX D: WHAT DO FACULTY DEVELOPERS RECOMMEND TO FACULTY FOR IMPROVING COURSE COMPLETION AND RETENTION?}

Thanks to members of the Sloan-C Faculty Development Advisory Board for posting tips they give faculty for helping students complete courses. You are welcome to add tips and comments to the blog at: http://www.sloanconsortium.org/node/2486.

- Open portions of the LMS course site before the semester starts. Giving students an early view of the syllabus, materials requirements, and a description of how the course will be conducted establishes a comfort level with the course requirements, design, and navigation. Early opening avoids last minute panic drops and establishes needed transparency from the start. 
- Set the tone for engaging the class in a community of purpose, "we're all in this together."

- Have personal interviews or phone calls with each student or with small groups so they feel personally connected with you and with each other.

- Remember that online roles and virtual learning platforms are still new for students (and faculty). In the earliest parts of the course, acknowledge that fact and help the students understand that learning the system of asynchronous interaction is a process.

- Use plain language rather than academese to convey friendliness and accessibility, introducing concepts first in plain language and gradually introducing the vocabulary of the discipline (see "Virtual Facilitators Help Students Become Rhetorically Savvy," http://www.sloanconsortium.org/node/1084 and http://www.plainlanguage.gov/)

- Emphasize the relevance of the course to students' everyday activities, other courses, and longterm goals. For example, begin with a course-related challenge to which everyone can respond, drawing on each person's prior experience and knowledge. But remember that some learners may not have a lot of professional experiences, or may not be confident in writing about experiences they have had. Be sure to engage less experienced learners so that they do not feel lost or overpowered.

- KISS. Keep the course operation as simple as it can be while maintaining course quality and effectiveness. DO NOT include gratuitous activities (even if they're really cool) that do not support the desired learning outcomes. Simplify the learning space while leveraging the most powerful communications technologies. Don't go overboard on the technology (no matter how cool it is!) such that it is distracting to learners.

- Make the structure of the course and expectations for overall flow explicit. Use tables, charts, mind-maps, advance and graphic organizers, photos, cartoons - whatever it takes to help students see how the pieces of the course relate to one another and more importantly, how the students themselves fit into all of it (i.e., where, when, how are they contributing to building the course content and their own understanding).

- Make content accessible for different preferences and abilities (see http://www.sloanconsortium.org/cannect home and Center for Applied Special Technology http://www.cast.org/research/udl/index.html).

- Link to student services and resources from within the course.

- Give students opportunities to practice with all functional/operational aspects of the course as early in the course as possible and in a low-stakes, non-threatening environment. Be certain to introduce all tools and systems that will be required later on in the course.

- Provide a detailed timeline for completing successive steps toward meeting the objectives (see UMUC Office of Evaluation and Assessment, Best Online Instructional Practices Study, http://www.umuc.edu/distance/odell/ctla/resources/bestpractices.pdf).

- Estimate time on task for assignments so learners get a sense of how they'll need to manage their time. Collect feedback on time actually spent to involve class members in co-design.

- Encourage self-direction and diversity by getting students to draw on their own experiences and perspectives as part of their learning and to incorporate their own goals into the work of the course (see UMUC Office of Evaluation and Assessment, Best Online Instructional Practices Study http://www.umuc.edu/distance/odell/ctla/resources/bestpractices.pdf).

- Encourage students to support each other, e.g. giving each other feedback and help on assignments before you assign a grade, perhaps even asking veteran students to help novices. Provide a "Student Cafe" where students can interact both in real-time or asynchronously outside of the classroom so that they can support each other. (see "Wizards" http://www.sloanc.org/node/240 and Brown, R. "The Process of Community-Building in Distance Learning Classes.” JALN 5:2, September 2001. http://www.sloanconsortium.org/publications/jaln/v5n2/v5n2_brown.asp). 
The Road to Retention: A Closer Look at Institutions that Achieve High Course Completion Rates

- Encourage divergent thinking so that students learn to consider alternative interpretations of their own or others' experience (see UMUC Office of Evaluation and Assessment, Best Online Instructional Practices Study, http://www.umuc.edu/distance/odell/ctla/resources/bestpractices.pdf).

- Set consensus rules with the class for discussions and other activities (see Wang, Y, Chen, V. "Essential Elements in Designing Online Discussions to Promote Cognitive Presence-A Practical Experience.” JALN 12(3): December 2008. http://www.sloanconsortium.org/node/1412).

- Scaffold problem-based or project-based approaches, enabling students to accomplish objective in small steps that can be revised as they lead to the completion of the final product.

- Present learning tasks in terms of problem solving, not only as accumulated knowledge, and encourage multiple approaches to problem solving (see UMUC Office of Evaluation and Assessment, Best Online Instructional Practices Study, http://www.umuc.edu/distance/odell/ctla/resources/bestpractices.pdf).

- Use audio and video for feedback to enhance immediacy (see "Asynchronous Audio Feedback to Enhance Teaching Presence and Students' Sense of Community,” http://www.sloan-c.org/node/1085).

- Use student-designed exam questions (see Shen, J., Bieber, M., Hiltz, S.R. "Participatory Examinations in Asynchronous Learning Networks: Longitudinal Evaluation Results,” JALN 9(3): October 2005. http://www.sloan-c.org/publications/jaln/v9n3/v9n3_shen_member.asp).

- Create a database of exam questions that students can answer to prepare for the final (see Heckman, R., Annabi, H. "Cultivating Voluntary Online Learning Communities in Blended Environments,” JALN 10(4): December 2006. http://www.sloan-c.org/publications/jaln/v10n4/v10n4 heckman member.asp).

- Think outside of the course management system to interact with people and resources that add relevance to course topics and skills. Use blogs, wikis, Twitter, FaceBook, YouTube, IM or other applications so people can stay in touch as the class proceeds. Use mobile learning as a way to connect learning to real-life. Be creative. For example, have learners upload their own photos, videos, or other objects created with mobile devices that relate to current topics (see, for example, Welcome to the Human Network video http://www.youtube.com/watch?v=hAdfYgEapT8\&feature=related).

- Give students opportunities to publish their work (see "What is Student-Generated Content?" http://www.sloan-c.org/effective/callforcollection and "Content Area Vocabulary Digital Stories," http://www.sloan-c.org/node/1162).

- If your LMS allows students to manage the available communication tools - turn them on and let the students choose how they want to work together. Here's an excerpt from a faculty member who was surprised most by the fact that students willingly took ownership of the learning space (Scroll forward to 1:35 http://www.unc.edu/sakaipilot/blog/?p=46).

- Provide frequent and regular checkpoints (both student and faculty managed) for measuring student progress and gauging student's grasp of course material. Low-stakes questions, automated "check your knowledge" or question forums can go a long way to keep students engaged and on track.

- Provide multiple points of contact to the instructor. These may include using an email to create a personal connection, discussion forums, blogging, or using the "announcements" to keep student's abreast of course progress.

- Flexibility in communication and delivery requires underlying structure and predictability. Set patterns of instructor communication and meet and keep scheduled updates; students may interact in various ways, but the instructor establishes the solid center. See the Community of Inquiry Survey Instrument in JALN 13(3) for ways instructors enhance community. 
- Use learning contracts and rubrics to help students track progress towards goals, but don't create overly-complex, verbose and restricting rubrics to explain your expectations. Leave room for quality, creativity and individualization to come through in assignments. Also consider providing several sample assignments so that learners can see examples of your expectations.

- Use discussions wisely. Avoid quantitative measures of engagement such as "post 5 comments every day" and devise grading schemes where discussion postings are evaluated on the quality of the overall participation, rather than the number of postings.See, for example, "(My) Three Principles of Effective Online Pedagogy" by Bill Pelz, JALN 8(3): 43, June 2004, http://www.sloan-c.org/publications/jaln/v8n3/v8n3_pelz.asp.

Thanks for the tips above to advisory board members: Allen Clarkson, Western Governors University; Nan Chico, California State University Eastbay; Phil DiSalvio, Seton Hall University SetonWorldWide; Kim Eke, University of North Carolina; Susan Ko, University of Maryland University College; Larry Ragan, Pennsylvania State University World Campus; Maria Puzziferro, Rocky Mountain College of Art and Design; and Shari McCurdy Smith University of Illinois Springfield.

\section{ABOUT THE EDITORS}

Janet C. Moore is the Chief Knowledge Officer for the Sloan Consortium. She is an editor for the Sloan$C$ View, the Journal of Asynchronous Learning Networks, effective practices, and annual volumes in the Sloan-C quality series. She participates in various initiatives, including helping design and conduct SloanC workshops and seminars, and Sloan-C Catalog reviews. She is the author of Elements of Quality: The Sloan-C ${ }^{\text {TM }}$ Framework, Pillar Reference Manual.

Marie J. Fetzner joined Monroe Community College (MCC) in Rochester, New York 1987 and currently serves as the Assistant to the Vice President for Educational Technology Services (ETS). In 2006-07, Marie served as Director of Online Information and Distance Learning at Montgomery College, Montgomery County, Maryland. From 2003-2006, she was on special assignment as MCC's Banner Project Manager. Marie is a founding member of the Monroe Model team that was created in 1997 to support MCC's online learning faculty and students. Marie serves on the editorial board of the Journal of Asynchronous Learning Networks (JALN), is a Quality Matters ${ }^{\mathrm{TM}}$ online course reviewer and is a peer reviewer on the Music editorial team for MERLOT (Multimedia Educational Resource for Learning and Online Teaching). She is an adjunct assistant professor (online) in MCC's Transitional Studies department and in the Visual and Performing Arts department. Marie is pursuing a Ph.D. degree in Education at the Margaret Warner Graduate School of Education and Human Development at the University of Rochester, where her research focuses on online student retention.

\section{REFERENCES}

1. Allen, I.E. and J. Seaman. Staying the Course: Online Education in the United States, 2008. SloanC, November 2008, page 5. http://www.sloan-c.org/publications/survey/pdf/staying the_course.pdf.

2. Statistical Abstract of the United States: 2010, Table $214<\mathrm{http} / /$ www.census.gov/compendia/statab/>

3 See retention efforts from the Gates Foundation http://www.gatesfoundation.org/postsecondaryeducation/Pages/default.aspx; the Lumina Foundation http://www.luminafoundation.org/our work/our initiatives/Achieving the Dream.html; the Carnegie Foundation http://www.carnegiefoundation.org/programs/sub.asp?key=26\&subkey=1835\&topkey=26; ; and the 
The Road to Retention: A Closer Look at Institutions that Achieve High Course Completion Rates

Education Trust and the National Association of System Heads

http://www2.edtrust.org/EdTrust/State+and+Local+K-16+Initiatives.

4. Association of Public and Land Grant-Grant Universities. Sloan National Commission on Online Learning. Online Learning Benchmarking Study and Faculty Survey. August 31, 2009. http://www.aplu.org/NetCommunity/Page.aspx?pid=282.

5. National Survey of Student Engagement. Promoting Engagement for All Students: The Imperative to Look Within, 2008 Results. Indiana University Center for Postsecondary Research. November 14, 2008. http://nsse.iub.edu/NSSE_2008_Results/docs/withhold/NSSE2008_Results_revised_11-142008.pdf.

6. Means, B., Y. Toyama, R. Murphy \& K. Jones. Evaluation of Evidence-Based Practices in Online Learning: A Meta-Analysis and Review of Online Learning Studies. U.S. Department of Education, Office of Planning, Evaluation and Policy Development, Policy and Program Studies Service. July 2009. http://www.ed.gov/rschstat/eval/tech/evidence-based-practices/finalreport.pdf.

7. Hiltz, S. R., \& M. Turoff. Network Nation: Human Communication via Computer. Cambridge, MA: MIT Press (1978), rev. 1993.

8. College Navigator. ACE Analysis of Higher Education Act Reauthorization. http://www.acenet.edu/enewsletters/p2p/ACE_HEA_analysis_818.pdf.

9. National Center for Education Statistics, U.S. Department of Education Institute of Education Services. http://nces.ed.gov/collegenavigator.

10. See for example not-for-profit rankings:

- American Council of Trustees and Alumni (ACTA) What Will They Learn? A Report on General Education Requirements at 100 of the Nation's Leading Colleges and Universities http://www.whatwilltheylearn.com/

- Association of American Colleges and Universities, the American Association of State Colleges and Universities (AASCU), and the Association of Public and Land-grant Universities (APLU) VALUE-Plus: Rising to the Challenge http://www.aacu.org/value/index.cfm.

- College Portrait of Undergraduate Education http://www.collegeportraits.org/.

- American Enterprise Institute for Public Policy Research. Diplomas and Dropouts Which Colleges Actually Graduate Their Students (and Which Don't). By Frederick M. Hess, Mark Schneider, Kevin Carey, Andrew P. Kelly. June 2009. http://www.aei.org/docLib/Diplomas\%20and\%20Dropouts\%20final.pdf.

- Transparency by Design http://www.collegechoicesforadults.org/.

- University and College Accountability Network, http://ucan-network.org/.

11. See for example news and commercial rankings:

- USNEWS Best Colleges 2010 http://colleges.usnews.rankingsandreviews.com/best-colleges, and USNews catalog of online programs at http://www.usnews.com/sections/education/onlineeducation/index.html.

- Washington Monthly http://www.washingtonmonthly.com/college_guide/rankings/national_university_rank.php/.

- Best Colleges Online http://www.bestcollegesonline.com/.

- Get Educated "Rate, Rank and Compare Online Schools and Degrees": http://www.geteducated.com/.

- Online Education Database http://oedb.org/rankings.

- College Crunch http://www.collegecrunch.org/rankings/top-25-online-colleges-ranked-for-2009/.

12. The College Navigator advises readers to "interpret data with caution."

13. Moore, J., M. Fetzner \& J. Sener. Getting Better: ALN and Student Success. JALN 10(3). http://www.sloanconsortium.org/publications/jaln/v10n3/v10n3 6moore member.asp.

14. 2008 SENSE National Report, Imagine Success: Engaging Entering Students: "nationally, nearly 50\% of entering students drop out before the second year.” March 18, 2009. http://www.ccsse.org/sense/. 
15. Sloan Consortium quality framework. http://www.sloan-c.org/5pillars.

16. In March/April 2009, a Sloan-C Workshop on Retention Strategies in Online Education discussed the extent to which particular pillars were emphasized in retention initiatives. A listing of workshop participant retention practices was prepared by the workshop facilitators, Ruth Bennett and Marie Fetzner.

17. Webber, D. A., R. G. Ehrenberg. Do Expenditures Other Than Instructional Expenditures Affect Graduation and Persistence Rates in American Higher Education? Cornell Higher Education Research Institute. August 1, 2009. p. 19. http://www.ilr.cornell.edu/cheri/upload/cheri wp121.pdf.

18. Tinto, V. Leaving College: Rethinking the Causes and Cures of Student Attrition. Second edition, University of Chicago Press, March 1994.

19. Di Salvio, P. Cohort Student Grouping: Does It Enhance Student Retention? http://www.sloanc.org/node/1553.

20. Swan, K. Relationships Between Interactions and Learning In Online Environments. http://www.sloan-c.org/publications/books/pdf/interactions.pdf.

21. Garrison, D. R., M. Cleveland-Innes \& T.Fung. Student Role Adjustment in Online Communities of Inquiry: Model and Instrument Validation. JALN 8(2): 64, April 2004. http://www.sloanc.org/publications/jaln/v8n2/v8n2_garrison.asp.

22. Top Ten Issues related to Scale. Sloan-C View, May 2003.

http://www.sloan-c.org/publications/view/v2n3/coverv2n3.htm.

23. A special issue of JALN focuses on institutional business models, see $J A L N$ 10(2): May 2006.

24. Gary Miller quoted in 'From 'Cost Effectiveness and Institutional Commitment' to 'Scale' The Sloan-C View, July 2008. http://www.sloanconsortium.org/publications/view/v7n7/viewv7n7.htm\#Scale.

25. Moloney, J. and B. Oakley. Scaling Online Education: Increasing Access to Higher Education. JALN 10(3): July 2006. http://www.sloanconsortium.org/publications/jaln/v10n3/v10n3_2moloney_member.asp.

26. Willging, P. A. \& S. Johnson. Factors that Influence Students' Decision to Dropout of Online Courses. JALN 8(4): December 2004. http://www.sloan-c.org/publications/jaln/v8n4/v8n4_willging_member.asp.

27. Tinto, V. Leaving College: Rethinking the Causes and Cures of Student Attrition. Chicago, IL: University of Chicago Press, 1987.

28. Bean, J. P. and B. S. Metzner. A conceptual model of nontraditional undergraduate student attrition. Review of Educational Research 55(4): 485-540, 1985.

29. Garrison, D. R., T. Anderson, and W. Archer. Critical inquiry in a text-based environment: Computer conferencing in higher education. The Internet and Higher Education 2(2-3): 87-105, 2000.

30. Meyer, K.A., J. Bruweilheider \& R. Poulin. Why They Stayed: Near-Perfect Retention in an Online Certification Program in Library Media. JALN 10(4): December 2006. http://www.sloan-c.org/publications/jaln/v10n4/v10n4_meyer2_member.asp.

31. The National Center for Academic Transformation. Fully online model: http://www.thencat.org/PlanRes/R2R_Model_Online.htm. 